\title{
Poverty, corruption, and religious opportunism in Africa: A Neo-Pentecostal perspective
}

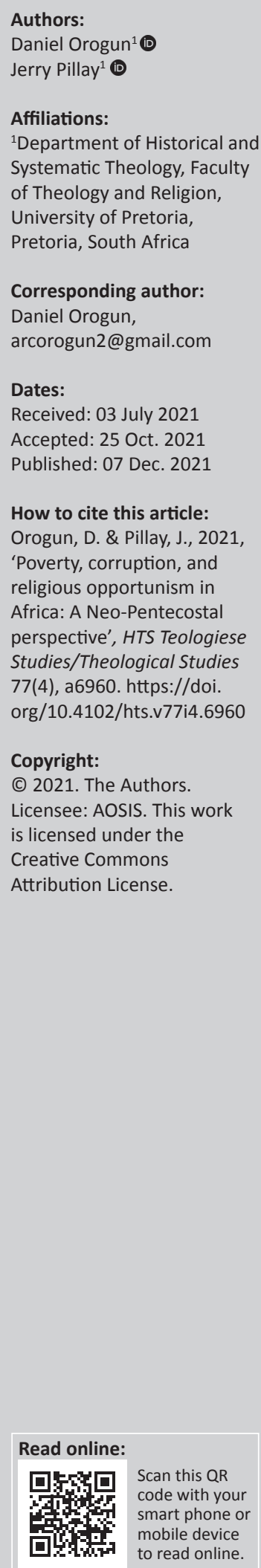

In an ideal context, religious tenets are perceived as antithetical to corruption on all fronts. Sadly, Africa takes a frontline in religious activities, yet is bedevilled by corruption aided poverty. Viewing some Neo-Pentecostal practices with the lens of contemporary Marxism hypothesis, and philosophical consciencism of Kwame Nkrumah and Fela Anikulapo, this article examined the role of religion in the spread of poverty in Africa. It further held that while a few religious leaders speak against corruption aided poverty, institutionalised and deliberate strategic plans have not been set up to combat corruption aided poverty. Subsequently, through strategic and implementable recommendations, this article serves as a wake-up call for Africa's religious institutions to jettison alliance with corrupt political entities and support anticorruption crusades in Africa.

Contribution: Employing the multi-play of Sociology, Economics, Philosophy and Theology, this article contributes to the interdisciplinary and international research of HTS Theological Studies.

Keywords: poverty; religion; opportunism; corruption; Marxism; philosophical consciencism; Neo-Pentecostalism.

\section{Introduction}

In the past, slavery and colonialism took a heavy toll on Africa; worse still, in contemporary times underdevelopment continues to bedevil African nations. In the opinion of the authors of this article, chief among many challenges in Africa remains the 'triogonocerous' ${ }^{1}$ nature of poverty which suggest that poverty lacks existential capacity, rather, it is aided and abated by a cause and a consolation. The 'cause' is corruption, while the 'consolation' is religion. These two have become weapons in the hands of political leaders in alliance with their religious counterparts to increase the rate of poverty disproportionately and advance their acquisitive venality. On this premise, this article seeks to contribute 'religeconomics'2 (Önday 2017) knowledge to research on poverty and religious opportunism ${ }^{3}$ in Africa. This article proposes that rather than aggravating corruption aided poverty, religion can take a frontline role in eliminating poverty. Thus, some socio-economic development strategies necessary for an alternative role will be recommended in the end. It is noteworthy that focusing on the Neo-Pentecostals does not deny the existence of poverty aided corruption and religious opportunism amongst other religions and Christian organisations. Likewise, this article recognises that there are other causative factors of poverty even in countries with lesser incidents of corruption and religious opportunism. However, this article concentrates on poverty that is caused by corruption and religion in relation to the Neo-Pentecostals.

Subsequently, the article will use as theoretical framework, the contemporary Marxian hypothesis on Karl Marx contribution to the critique of Hegel's philosophy of Rights in 1844, where he argued that 'religion is an opium of the masses'. This contemporary thought will be used to propose the need for an alternative imagination of religion in the space of poverty. Additionally, Kwame Nkrumah and Fela Anikulapo's philosophy on the socio-moral and socio-economic effect of religion will be used to delineate the past and the current role of religion in the escalation of economic extortion. In the end, it will be clear that shifting from a popular approach to an

1.By 'triogonocerous' nature of poverty we mean that three subjects enable poverty in Africa namely, poverty, corruption and religious opportunism. By implication, poverty does not have existential capacity; it plays out via two other socio-moral and socio-economic activities, which are corruption and religion.

2.'Religeconomics' is a short form of 'The economics of religion'. It is an interdisciplinary study that showcases the interplay of religion and economic activities (Önday 2017).

3.'Opportunism is the art, policy, or practice of taking advantage of opportunities or circumstances often with little regard for principles or consequences' (Merriam Webster n.d.:n.p.). 
alternative imagination can help in reforming the role of religion and combating the plague of poverty in Africa. In sequential order, these theories will be briefly discussed in the second section. Correspondingly, the third section will address poverty in Africa in the context of corruption, while the fourth section will address poverty in the context of religious opportunism. Before the conclusion, the fifth section will delineate a theological perspective and make recommendations with a focus on the alternative role of religion in the face of poverty aided corruption.

\section{Philosophical consciencism and contemporary Marxism on religion as an opiate}

\section{Fela Anikulapos moral philosophy on religions}

Late Fela Anikulapo was a Nigerian musician, Pan African activist, and an African moral philosopher tutored by Kwame Nkrumah, the father of African Philosophical Consciencism. Olaniyan Tejumola, a Professor of English, African languages, and literature at the University of Wisconsin-Madison, documented Fela's album that rightly described his philosophy on 'Religion and Capitalism'. In his classic song titled: 'Shuffering and Shmilling', Fela spoke about Christian and Muslim leaders as 'profiteering men of God'. Fela's voice hit the highest pitch against the capitalists' religious leaders. In separate titles 'Who are you' and 'Na fight $\mathrm{O}$ ', Fela described them as 'aiders of capitalism' because of their capitalistic ideology in religious dispositions and practices (Olaniyan 2009:88-89). In Fela's opinion, both religions are instruments of securing undeserved advantages with titles like Reverends, Alhajis or Alhajas. ${ }^{4}$ Thus, both religions become tools of economic competition and accumulation in desacralising dependent capitalism. Concomitantly, to obtain an undeserved economic advantage, the two religions are founded on 'submissive theologies'. In other words, they manipulate followers to submit to economic exploitation. As Olaniyan (2009) described it:

[T]hey dole out opium through the promise of paradise in heaven as solace for hard times on earth, whereas the priests jostle with soldiers or military regime dictators, businessmen and bureaucrats for the grand price for acquisitive venality. (p. 89)

Invariably, Fela's ideology on the negative role of submissive theology agrees with the contemporary Marxists' thoughts that religion as an opiate can aid the collaboration of religious leaders with the corrupt political actors to perpetuate corruption and thereby inflict poverty on the African populace.

Furthermore, Fela's description of African religious leaders as 'profiteering businessmen of God' in the same album agrees with the possibility of religious opportunism. According to Olaniyan (2009:91-93), the song was rendered to expose crooked and hypocritical religious leaders. Also, a portion of the rendition unapologetically took a swipe at 4.Alhaji and Alhaja are Islamic titles obtained after a pilgrimage to Mecca. masses who run to religious charlatans and illusionists. The lyrics which began with the popular chorus 'suffer, suffer for world' sent a strong message to the masses that they contributed to their sufferings in this world by voluntarily becoming dependent on religion and its exploitative consequences (Olaniyan 2009:91-93). Correspondingly, Fela accused religious leaders of corruption and money laundering while their followers remain in abject penury. Thus, the summary of Fela's socio-moral message raises a sharp moral critique of the use of religion to exploit the masses (Olaniyan 2009:96-98).

\section{Nkrumah's connection of philosophy with religion, spirit world and exploitation}

Nkrumah's position on theology can be traced to his religious foundation. His autobiography revealed that he admittedly called himself a 'non-denominational Christian and a Marxist socialist' as he found no contradiction in the duo (Nkrumah 1970:10). Nkrumah did not deny the existence of spirituality; however, he looked at the origins of things vis-à-vis selfsufficiency and emancipation from white capitalistic activities. He believed that the indigenous bourgeoisie, which included religious leaders, used the outside world or spirit world concept to propagate the exploitation of the masses (Nkrumah 1970:10). One must then ask the question: How did the exploiters use the philosophy of origins to their advantage? Nkrumah upheld that when the process of conversion of the 'inside-outside world' is twisted or adjusted, a contradiction between interests inside and outside the world is stared (Nkrumah 1970:10). Thus, the exploiters project their interests by encouraging followers to focus on the outside world and ignore what goes on inside the world. They are expected, as seen in Christianity, to lay up treasures in heaven (outside world), implying that their poverty and exploited state inside the world is irrelevant. In Nkrumah's (1970:12) words, 'when the gaze is fixed upon things in the outside world, the requirements of earthly life which condition the existence of human beings suffer neglect'. By implication, the social life and expectation of basic social necessities inside the world do not count. This is strategic to the assimilation of oppression and exploitation. Additionally, Nkrumah suggested that this ideology triggered Marxist criticism of religion as an instrument of exploitation because religion was used to divert workers' attention from the value which they had created by their labour to outside world concerns (Nkrumah 1970:12).

Consequently, this twisted transcendentalism shows how the Afro-religious capitalists and foreign colonialists used cosmic contrast ideology as a device to exploit Africans by diverting their attention from social needs, while they hold onto everything material including mineral resources in the earth realm. It is on this note that Nkrumah called religion an instrument of bourgeois social reaction because its social use is not only by the imperialists and colonialists; politicians and religious leaders use it for unethical gains. Thus, Nkrumah called for a consistent emphasis on the African states as secular rather than religious; otherwise, 
economic exploitation will continuously ravage Africa (Nkrumah 1970:13). Invariably, Nkrumah implies that to declare war against religious exploitation, there is a need to establish a society that caters for the basic needs of the people.

\section{Contemporary Marxists and the opium of the people}

The general interpretation of religion as the opium of the people seems to suggest that Marx calls religion evil rather than the use of religion. According to Boundless (2020:920), Marx's original idea lies in the function or applicability of religion. From a sociological perspective, the structural and functional approach to religion has its root in Emile Durkheim's thoughts. Durkheim (1897) proposed that religion which is about the celebration and worship of human society has three major functions in society which are social cohesion, social control, and provision of answers to existential questions (cf. Thorlindsson \& Bernburg 2004:271-285). However, in Boundless report the main criticism against this structural function approach is that it overlooks the dysfunctionalities of religion. For example, religion can be used to justify terrorism and violence. It has been used to justify war and, in some cases, ethnocentric crisis (Boundless 2020:920). By interpretation, if religious dysfunctionality reflects immoral and dehumanising acts, it can as well aid corruption. Correspondingly, Thompson (2009) agreed that the original Marxists context has become divorced from its meaning. Thompson (2009) asserted that religion is used as endorphin; it forces people to cope with pain or endure what can be changed for good. This further suggests that the intent of Marx's thought is the appropriation of religion.

Carmody (2009), in his contemporary context opined that Marx argued that religion was constructed by people to calm the uncertainty over our role in the universe and society. Marx took a stand against the use of religion based solely on what can be called applied science. This is so because Marx was more concerned about human development and not science for the sake of knowledge. Likewise, Christiano, Swatos and Kivisto could not agree less that Marx did not believe in science for science's sake; in their words: 'Marx believed that he was also advancing a theory that would be a useful tool in effecting a revolutionary upheaval of the capitalist system in favour of socialism' (2008:124). In other words, in Marx's opinion, religion plays a critical role in maintaining an unequal status quo, in which certain groups of people have radically more resources and power than other groups of people. Thus Carmody (2009), Christiano et al. (2008) and Thompson (2009) all hypothesised that Marx argued that the bourgeoisie used religion as a tool to keep the less powerful proletariat pacified. Thus, religion was able to do so by promising rewards in the afterlife.

Furthermore, in a London School of Economics publication, Cronin (2018) gave a more contemporary account of the Marxian phrase - 'Religion is the opium of the people'. He claimed that the initial interpretation of Karl Mark's statement was decontextualised in the sense that it creates the impression that Marx was anti-religion or antiChristianity. Cronin noted that in the contribution of Karl Marx to the critique of Hegel's Philosophy of Rights (1844), there was a previous statement before the concluding phrase. Karl previously said that 'Religion is the sigh of the oppressed creature, the feeling of a heartless world, and the soul of soulless conditions'. In Cronin's opinion, in a proper context, the contemporary Marxists believe that while Marx saw religion as an understandable yet unhelpful response to societal inequality, marginalised groups tend to be more religiously observant. This suggests that contemporary Marxists agree with Fraser (2017) that the more people are oppressed and marginalised economically, the more their religious instincts are stimulated. Consequently, Marx's quote takes on a very different context as against the generalised interpretation. Contemporary thinkers like Schnabel (2020:1) opined that Marx sees opium as an expression of feelings or reactions of the people in a heartless world. Contemporary Marxists held that Marx argued that humans are best guided by reason rather than being controlled by religion. Whereas religion encouraged social alienation and opposition to reason thereby masking the truth and misguiding followers. For Marx, this social function of religion is at the heart of social inequality and the antithesis to this alienation is freedom. Thus, to propagate freedom means to present individuals with the truth and give them a choice to accept or deny it. In this context, contemporary researchers hypothesise that Marx never suggested that religion ought to be prohibited (see Boundless 2020:924; Cronin 2018; cf. Christiano et al. 2008:126).

Unvaryingly, the contemporary impression suggests that Marx called for a revolution that implies freedom to reason on social issues like corruption. Marx's point was not about prohibition but revolution as he viewed religion as a tool of social control used by the bourgeoisie to keep the proletariat content with an unequal status quo. He wants action taken to resolve social inequalities. It can then be inferred that the crux of Karl's argument against religion is not religion itself, but the type of society that causes suffering and creates the opportunity for religion to give a response that denies the reality of the people's problems. In contemporary view, Cronon (2018) then suggested that anyone under the influence of religious fantasy will be detached from the reality of oppression created by the systems of political actors and their cronies (cf. Fraser 2009:1). Cronin (2018) therefore advised that religious adherents must identify with their unnatural suffering as a material situation that can be changed in this life. To achieve this, they need to throw off religious fantasy because its very purpose is to make them accept their subjugation.

In summary, contemporary hypothesis suggests that the problem is not 'religion' but its use as a subjugation pill to accept social, economic, and political situations that can be changed in this world. Thus, contemporary Marxism is calling for a change of approach in the applicability of 
religion. Indeed, this article opines that both Fela Anikulapo and Nkrumah's positions are in synchronicity with the view of contemporary Marxists. They are all not against religion, but are opposed to the use of religion by religious leaders as an oppressive tool in alliance with capitalists and state actors to foster poverty in Africa.

\section{Poverty in the context of corruption in Africa}

Beegle (2016:2) observed that among the 10 top countries with the highest rate of inequality, seven are in Africa. More precisely, as at the time of this report Beegle (2016:4) further noted that Africa will not meet the Millennium Development Goal target of halving poverty, and projections are that the world's poor will be increasingly concentrated in Africa. Also, in World Data Lab, Zachary (2020) noted that poverty is concentrated in Africa, with over 150 million people living in extreme poverty in just two countries - Nigeria and the D.R. Congo. Further projection is that nearly $90 \%$ of the countries unable to eliminate poverty by 2030 will be in Africa. The report summed up that roughly $40 \%$ of people in Africa live below US\$1.90 a day. Invariably, Nigeria has been rated as the world headquarters of poverty, yet it has the world's richest religious leaders (See Abdullahi 2019). Likewise, South Africa's Department of Statistics 2019 report shows that the food poverty line (FPL) per person per month stands at R547. This implies that an average South African lives on R18.70 or \$1.20 daily (Statistics South Africa 2019). In Rwanda, the 2017/18 National Statistics Report reveals that despite the progress since 2000, poverty remains widespread. In the most recent living standards survey, it was revealed that $45 \%$ of the population lived below the national poverty line, and $24 \%$ was considered extremely poor. Invariably, on the international scale, $63 \%$ of Rwandans live on about $\$ 1.25$ a day (National Institute of Statistics of Rwanda 2016/17).

In the 2016 Corruptions Perception Index (CPI) of Transparency International (TI), countries like Somalia, Senegal, Namibia, Rwanda, South Africa, Niger, Burkina Faso, Guinea, Nigeria, Ethiopia, Zimbabwe and Kenya maintained a rise in corruption between the year 2012 and 2016 (Nations Online n.d.). Connecting poverty to corruption, economists and researchers concluded that corruption constitutes a major problem in the developing world. Gupta, Hamid and Rosa (2002:23-45) opined that it exacerbates the difference between the rich and the poor. For Shleifer (1997:385-410), it creates obstacles to economic and political reform. In the analytical summary of Kaufmann, Kraay and Mastruzzi (2005:1-35), corruption can, in the long run, cause very considerable losses of human welfare.

By inference, the analyses above are not unconnected to leadership challenges. To take a position that poverty is aided by corruption is to indirectly hold political leaders responsible. Over the years, among many, presidents like Robert Mugabe
(Chin'ono 2019), Sani Abacha (BBC News n.d.; George 2020), Jacob Zuma (Burke 2021), Peter Mutharika (Africanews 2021), Bakili Muluzi (Muisyo 2016), William Ruto; vice president of Kenya (Herbling 2018), African ministers and governors of states or provinces were accused of corruption (Reuters 2016; McConnell 2011; Kiewit \& Rabkin 2019). In 2015, at the World Economic Forum, John Kerry the former U.S. Secretary of State specified that the military generals' corruption inhibits Nigeria's ability to combat Boko Haram insurgency. Likewise, more than 50 people in Nigeria, including former government officials, stole $\$ 9$ billion from the treasury (U.S. Department of States 2015). Kerry further stated that 'corruption is a social danger because it feeds organized crime, it destroys nationstates...and destroys the future' (U.S Department of States 2015). Kerry underscored that:

[C]orruption is a radicalizer because it destroys faith in legitimate authority. It opens a vacuum which allows the predators to move in. And no one knows that better than the violent extremist groups, who regularly use corruption as a recruitment tool. (U.S Department of States 2015:n.p.)

\section{Kerry noted that:}

[C]orruption discourages honest and accountable investment; it makes businesses more expensive to operate; it drives up the cost of public services for local taxpayers, and it turns a nation's entire budget into a feeding trough for the privileged few. (U.S Department of States 2015:n.p.)

These statements established that corruption in governance causes poverty in Africa. Sadly, while leadership is at the centre of this misdeed, citizens are also culprits in the corruption game. In the next subsections, we will delineate the leaders' / followers' role in poverty aided corruption.

\section{The algorithm and effect of leaders and masses' corruption in Africa}

Poverty aided corruption has its root in the participation of both government officials and masses - consumers of public services. On this background, this article categorises poverty aided corruption into three: street-level corruption, grand organised corruption and evasion of prosecution aided corruption. Meanwhile, more focus will be on the first two.

\section{The street-level and grand organised corruption}

In the research findings of Mogens and Bjørnskov (2012:1-2), the key motivation for paying bribes in Africa is access to basic public services, such as education, water, permits and licenses, or legal enforcement. If, for example, a public water supply is not available, getting water may be difficult and highly costly. Thus, citizens pay incentives to public officials to protect themselves from such situations. This level of engagement can be called street-level corruption. Mogens and Bjørnskov analysis showed that people living in less developed countries are generally more exposed to bribery and corruption (Mogens \& Bjørnskov 2012:24, cf. Hunt \& Laszlo 2012:355-372). Contrarily, Mocan's macro-level analysis asserted that wealthier people in Africa are more likely to pay bribes (Mocan 2008:493-510). Technically, whether macro or micro-level 
analysis, the underlining denominator is that poverty and corruption are interconnected in Africa.

Congruently, the organised grand corruption speaks to the acquisitive venality of government officials who are trusted with leadership by the African people. Most impacted are the private sector businesses. Thus, corruption in the government/private enterprise relationship impact negatively on job creation, economic activities and causes widespread poverty. For example, the United Nations Office on Drugs and Crime (UNODC 2009:1) conducted a survey in 2007 on a sample of 2775 enterprises that were randomly selected to represent businesses active in Nigeria. In the final analysis, $75 \%$ of interviewees said that crime and corruption represent serious obstacles to doing business. Averagely, one out of three enterprises had to pay a bribe to public officials when carrying out certain administrative procedures (UNODC 2009:2). Besides, the looting of treasuries stands atop all kinds of corruption aided poverty in Africa. As mentioned earlier, some government functionaries use their offices through organised corruption to sink Africans into the pool of abject penury. Subsequently, a wide gap of inequality is created leaving the majority below the poverty line. This article will now delineate inequality as an effect of corruption aided poverty in Africa.

\section{Inequality as an effect of corruption aided poverty in Africa}

Inequality is caused by a lack of transparency and accountability which allows institutional corruption. The United Nations Development Programme (UNDP) (2017:71) report suggested that non-transparent and non-accountable institutions remain key determinants of the high levels of inequality in Africa. Additionally, Keeley (2015:66-67) underscored some economists' thoughts on inequality which gives evidence that poverty bites more on the poor as they are unable to invest in education, health, and basic needs. For the middle-class, inequality squeezes their demands for goods and services, but it allows the rich to accumulate more savings thereby increasing their economic power to lobby against policies that do not serve their interest. Summarily, the lower class of the society are at the receiving end of inequality, which is an effect of corruption aided poverty perpetuated by political and religious opportunists in Africa. We will now discuss poverty and religious opportunism.

\section{Poverty in the context of religious opportunism}

A research followed by a scientific data analysis by Mogen and Bjørnskov (2012:15-17) revealed that religion in Africa contributes to increase in poverty. The research showed that religious organisations are not exempted from street-level and grandly organised corruption. Although the percentage of the religious group seems lower than other sectors listed, it indicates that religious institutions participate in corruption. In Kenya, Professor Lumumba (2015) openly accused African Pentecostal preachers of their unholy alliance with the political class. Although he acknowledged some good ones, many of them are influence peddlers and businesspeople who give certain politicians who are otherwise thieves, avanias of spiritual legality. Lumumba held that it may be arduous to stop this narrative because when people invoke the name of God, the congregation is frozen. Sadly, many adherents cannot interrogate the situation. Likewise, Fela Anikulapo (Olaniyan 2009:89) was convinced that the pastors throw submissive theology at the adherents as a solace for hard times whereas they form an elitist alliance with those in power for the grand prize of acquisitive venality.

In another instance, Mahdi Shehu narrated a perfect example of corruption and religious opportunism. In his words, 'it is only in Nigeria that people steal from public treasuries yet receive national honours afterwards' (Mahdi 2021). He testified that a former bank managing director stole 3 billion naira from shareholders' funds. The accused was arrested and taken to court. While awaiting the trial, two prominent Islamic scholars, popular members of a Northern Elder Forum and Jama'atu Nasril Islam (JNI) visited the then president. Consequently, the attorney general intervened and got the accused off the hook. A few years later the accused was conferred with a national award. Likewise, a South-South Governor stole 30 billion naira, rather than going through prosecution, the South-South Elders forum and the Secretary-General of Christian Association of Nigeria (CAN), visited Mr President. The entourage sued that the money stolen by the Governor does not belong to the federal but state government, therefore they represent the people to declare their forgiveness on the stolen funds. Thus, the visit marks the end of the case. Mahdi (2021) in his narrative then wonders if Christianity and Islam are about forgiveness of stealing and looting. Shehu accused the religious groups of wearing the face of Moses while hanging the heart of Pharaoh. He finally asserted that Africa cannot progress with this corrupt religious intervention while the treasury of the nation bleeds.

Besides alliance with political leaders, Neo-Pentecostal prosperity preachers take advantage of the people's poverty to strengthen their theology of exploitation. Invariably, the failed political leadership is an opportunity to commodify the gospel in Africa. For example, Appau and Bonsu (2020:1-2), investigated a commercial practice of spiritual consultancy in Ghana and realised that a historicised marketisation of religion supported the practices of contemporary spiritual consultants. Such consultants include church pastors, traditional priests, and Islamic spiritualists (mallams), and by extension Neo-Pentecostal leaders. The members run to the pastors to escape from poverty, but they are enmeshed in a deeper state of poverty while the preachers get richer by the day. Although some Pentecostal leaders genuinely want socio-economic change for their people through the prosperity gospel, others make a business out of it. This article will now give a few Neo-Pentecostal examples to give evidence of the use of religion to enrich the leaders at the expense of the adherents. 


\section{Selected examples of Neo-Pentecostal religious opportunism}

Neo-Pentecostal activities are quite vast in the African continent; thus, this article only covers a few samples from East, West and South Africa. This does not represent priorities or preferences. In the same vein, this article would like to put it on record that not all African Neo-Pentecostals use religion as an opportunity to exploit or increase poverty amongst the adherents and masses. We will now discuss the few examples of Neo-Pentecostal religious opportunism.

\section{Alleged land grabbing}

In a Pararan Mock News live video broadcast (2021), a family made a public appeal to Rev Chris Oyakhilome, the General Overseer of Christ Embassy to intervene and return the family property put on sale by the Warri branch of the church. Earlier on, under the influence of the 'give and get more' message a son in the family donated the family house with documents to the church. The entire family were not aware until the church placed a sale advert on the property. In the bid to escape the disaster of homelessness and the scourge of poverty, the entire family cried out for the intervention of the General Overseer after several abortive efforts to stop the branch church from selling their only property. In response, Daddy Freeze $^{5}$ scripturally condemned the act and joined the family in appealing to Oyakhilome to return the house documents. Although the Sower claimed he made the highest contribution during the building project, nevertheless, it is not enough reason to sow the house as a seed. On the grounds of moral and religious tenets, the acceptance and sale of the property by the church without full verification of ownership may amount to land grabbing. The question is why will an individual take such an action at the expense of his family. The most reasonable answer will be that he believes in the prosperity doctrine of 'give and get more'. He trusted the process; hopefully, the family will get more and better properties over time. This situation speaks to the fact that adherents give in the quest for a better life and opportunities to escape poverty. Unfortunately, the religious organisations had always taken the adherents' plight as a window to grab more while the members remain in abject penury.

\section{The Ugandan experience of religious opportunism}

The financial influence of Ugandan Neo-Pentecostal preachers deserves a critiquing lens. While the country goes through human rights abuse and high-level poverty, Uganda's prosperity preachers remain the richest in the country. Ivan (2020) allegedly listed the 10 richest pastors in Uganda. More precisely Thomas (2020), called out their net worth. The richest five have a net worth between $\$ 128$ and $\$ 910$ million, while the wealth of the last five range between $\$ 41$ and $\$ 115$ million. According to Beegle (2016):

$[U]$ nder the so-called prosperity gospel, many Pentecostal preachers tell worshippers that in return for donating huge sums

5.See the details of Daddy Freeze's corresponding appeal to Christ Embassy General Overseer at https://www.facebook.com/watch/?ref=search\&v=449136812804185\& external_log_id=ddd0dc404-6ec2-4ec4-8f68-1451541bdddc\&q=Daddy\%2OFREEZE of money, they will be cured of diseases and rewarded in material wealth several times over. (n.p.)

Guyson (2016) further alleged that Bugingo, one of the richest pastors accused his colleagues of extorting congregants. Unfortunately, he was counter-accused of hypocrisy as he recently raised $\$ 2.5$ million to purchase a new church facility. These allegations suggest that Ugandans' poverty state gave rise to the popularity of the prosperity gospel. Consequently, prosperity gospel activities escalate poverty as it takes away money from the impoverished citizens to expand the wealthy religious opportunists.

\section{Religious opportunism during the COVID-19 pandemic}

In a live video, Johnson Suleman stated that 'In COVID-19, I bought a jet. The third one. I have three. I was praying for COVID not to end because I was resting while people were complaining. My wife asked - "Can life be this sweet?"” (Sahara Reporter 2021). Subsequently, gospel ministers, religious and non-religious adherents across the globe condemned the statement. When confronted by critics, Suleman's response was affirmative. In his words (Sahara Reporters 2021):

$[T]$ hey said...He has a machine that prints money....and somebody asked if it is true, and I said it is. I said I already bought the machine; when you speak in tongues, you are printing money. (n.p. ${ }^{6}$

If this information is true, it will be inhuman to pray for the continuity of the COVID-19 pandemic in the face of increasing death, closure of schools and economies of private and public enterprises, and the lockdown of millions of people. Although Johnson Suleman does some charity for widows and friends, praying for the continuation of COVID-19 calls the genuineness of his charity to moral questions. While his charity efforts are appreciated, this action may suggest a double standard. It is human to be charitable, but inhuman to wish the beneficiaries of such charity and millions of other people across the globe a continuous suffering motivated by the adverse impacts of the COVID-19 pandemic. Besides, claiming that speaking in tongues is a money-printing machine represents a dangerous and chaotic prosperity theology. It suggests an antibiblical principle of work. It validates spending more time in religious activities rather than balancing work and faith. Such a doctrine can increase poverty by paralysing economic and industrial activities in any society.

\section{Alleged alliance between preachers and politicians}

Shepherd Bushiri is currently undergoing criminal and corruption trials in South Africa. An earlier report in 2017 alleged that Bushiri funded the then opposition party of the current Malawian president (see Nyasa Times 2017).

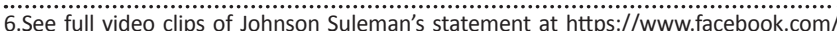
bbcnewspidgin/videos/viral-video-for-covid-pandemic-i-buy-my-jet-apostlebbcnewspidgin/videos/viral-video-for-covid-pandemic-i-buy-my-jet-apostlesuleman/446764093441544/, https://www.youtube.com/watch?v=VDWFwEfCyBo (BBC News Pidgin 2021) and http://saharareporters.com/2021/02/17/i-bought-mythird-private-jet-during-covid-19-pandemic-prayed-disease-stay\%E2\%80\%94-
apostle (Sahara Reporters n.d.). See example at https://www.youtube.com/watch?v=JuN2fnm3Wag (CelebrationTV 2018) 
Unfortunately, the trial took a downturn when the Prophet escaped South Africa. Two points raised by South Africans may have indicated an alliance between the political and religious leaders in this sense. Firstly, Bushiri holds a diplomatic passport of Malawi. Secondly, he escaped in the same period the Malawian President visited his South African counterpart. Meanwhile, the Malawi information minister had denied the allegation following claims that Prophet Bushiri took a ride with the President to escape his prosecution (eNCA 2020). In the opinion of Tsedu (2020), the Chief Executive Officer (CEO) of the South African Institute of Foreign Affairs:

If reports that the Malawi constitution protects holders of diplomatic passports from any extradition is true, then South Africa may as well close the chapter...It is bad for the Malawi government if Bushiri was truly smuggled by his President.

Likewise, Tsedu (2020) reported that Levy Ndou, a Tshwane University of Technology political analyst stated that 'South Africa must pursue the matter diplomatically because the Malawian government is not likely to bring Bushiri back' (ibid). If these allegations are true, it may imply that corruption aided poverty can be influenced by the alliance of the political and exploitative religious leaders especially in 'prosecution evasion' corruption.

Overall, it is pathetic that in a continent where dilapidating health and living conditions are very high, Neo-Pentecostal miracle evangelists become opportunists. The factors such as the desire to escape poverty, and the lack of financial capacity for health and housing expenses pushed many adherents to seek an escape route. To meet the peoples' demands, many of these evangelists sell miracle water, handkerchiefs, anointing oils, and so on. In some cases, adherents must register via payment to see these miracle evangelists for counselling, prayer, and deliverance consultations. In a nutshell, religion, if not rightfully and morally appropriated in Africa will continuously take the posture of religious opportunism against the masses while advancing the course of the wealthy.

\section{Theological discussion and recommendations}

It is evident from the discussion in the third section, that poverty can be created by failed governance and escalated by religious opportunism. While the political leaders breach social contract with the people, their religious allies serve the opium to create hope through theology of suffering that assures a pie in the sky. Consequently, the people forget their sufferings here on earth and focus on heaven where everything will be fine and good. This suffering model is circumvented by the Neo-Pentecostal prosperity theology which seeks to provide an alternative to suffering here on earth. Correspondingly, the 'give and get theology' sets in and extract more from the adherents. In the end, both the religious and political leaders become gainers. Thus, the position of this article is that religion must not be used as a trojan horse to circumvent the socio-economic rights of Africans.

Theologically, a few examples show that priests and prophets should stand against all odds and speak for citizens' rights. In 1 Kings 12, while the elders as representatives of the people advised Rehoboam to uphold servant leadership, he opted for oppression and artificial poverty. Such eldership position is required in the contemporary church. Also, in 1 Kings 13, when Jeroboam transgressed the laws of God which at that time serves as the constitutional document of Israel, a prophet rose to the occasion. Although the king tried to bribe him in verses 1-10, the Prophet stayed off the hook. Sadly, in the following verses, an older prophet who perhaps may have had an alliance with the corrupt royalty at that time, convinced the young prophet to do otherwise. In verses 23-33, it was obvious the prophet was judged. Thus, the effect of corruption does not spare the religious leaders who may compromise their position as agents of anti-corruption and change. There is a need for an uncompromising moral standard amongst religious leaders especially the Neo-Pentecostals, to reject alliances with socio-economic and political oppressors. More so, collaborative accountability towards uncompromising stand against exploitation and corruption amongst minsters is instructive.

In another instance, the narrative in 1 Kings 21, expressed the perfect scenario of economic oppression by the ruling class. Naboth, the Jezreelite was murdered on the premise of the greed and corruption of Ahab. Rather than supporting Naboth with government funding to expand his agricultural business, Ahab decided to hijack the business. Thankfully, Elijah a religious leader who represented the face and the voice of anti-corruption and justice stood against Ahab. Interpretively, African religious leaders especially the Neo-Pentecostals must rise as voices of justice and anti-corruption to speak for the masses. Additionally, African Neo-Pentecostal leaders have rarely been at the forefront of the anti-corruption campaign. While leaders like Father Mbaka, Archbishop Thabo Makgoba, Father Kukah and Bishop David Oyedepo spoke several times from the pulpits against bad political leadership, the fact remains that a core strategic plan and structure to be the voice of the people is lacking. Even in a country like South Africa, the same drive that propelled the South African Church against the apartheid regime is needed to stand against corruption in these contemporary times. We will now make further recommendations below.

\section{Deliberate plans and action to be anti- corruption crusaders}

The elimination of extreme poverty must be founded on a comprehensive accountability strategy in Africa. The Neo-Pentecostals must actively collaborate with other denominations, non-governmental organisations, anticorruption agencies, and civil society groups to design concrete and workable strategies, to hold public officers accountable. Pulpit criticism is not enough for this level of 
engagement; religious leaders must deliberately be anticorruption crusaders in Africa. This may include registering, funding, and running anti-corruption agencies as parachurch.

\section{Engaging the alternative theology}

Rather than sustaining the kind of theology that releases endorphins and allows the people to acclimatise and accept oppression and manipulation, religious leaders should promote liberation theology which seeks to address the unjust conditions of the wretched of the earth. Currently, prosperity theology and eschatological teachings are used to create false hope. Liberation theology as an alternative is highly recommended for the African Neo-Pentecostals to stand against oppression and demand social and economic justice. This is a good alternative imagination of theology needed in Africa and for Africans.

\section{Equipping leaders and followers for effective public engagements}

Public theology is not popular among the African NeoPentecostals. Should it find expression in their curriculum, Neo-Pentecostal Bible schools will become equip centres for socio-economic and socio-political engagements. Thus, the socio-economic rights of adherents vis-à-vis sustainability will be on the front burner of Neo-Pentecostal ministries. Additionally, the knowledge of public theology will assist the Neo-Pentecostal leaders to train congregants interested in political office some level of civic theology which includes public accountability and commitment to transparent servant leadership.

\section{Engaging 'charity begins at home' concept}

In leading an anti-corruption war, the home front must be in order. The cases listed in the third section and many more in the public domain need urgent attention. When the church addresses the culture of exploiting adherents economically via prosperity gospel, the concept of 'charity begins at home' would have been implemented. Only then will the church have the moral authority to demand accountability from the political class.

\section{Conclusion}

This article established that religion as an intrinsic part of humanity has come to stay. However, its misappropriation must be rejected. If political corruption continues to hinder the fulfilment of the social contract between the politicians and masses, religious opportunism will gain more ground. Marx's contemporary opinion is that the feel-good factor provided by religion in the face of socio-economic and sociopolitical corruption needs not to be adjusted but revolutionised. The theological approach of religious leaders needs to change from masses' 'endorphinisation's to emancipation. This will encourage logical contemplation such that citizens and religious adherents can think freely and make the decision to accept or reject socio-economic and political oppression.

\section{Acknowledgements Competing interests}

The authors declare that they have no financial or personal relationships that may have inappropriately influenced them in writing this article.

\section{Authors' contributions}

D.O. wrote the original draft and J.P. contributed to the review and editing of the article.

\section{Ethical considerations}

This article followed all ethical standards for research without direct contact with human or animal subjects.

\section{Funding information}

This research received no specific grant from any funding agency in the public, commercial, or not-for-profit sectors.

\section{Data availability}

Data sharing is not applicable to this article as no new data were created or analysed in this study.

\section{Disclaimer}

The views and opinions expressed in this article are those of the authors and do not necessarily reflect the official policy or position of any affiliated agency of the authors.

\section{References}

Abdullahi, M.S., 2019, 'Three things Nigeria must do to end extreme poverty', World Economic Forum, viewed 10 July 2020, from https://www.weforum.org/ agenda/2019/03/90-million-nigerians-live-in-extreme-poverty-here-are-3-waysto-bring-them-out/.

Africanews, 2021, Malawi ex-President Mutharika loses bid to unfreeze his accounts, viewed n.d., from https://www.africanews.com/2021/01/24/malawi-expresident-mutharika-loses-bid-to-unfreeze-his-accounts//.

Appau, S. \& Bonsu, S.K., 2020, 'The spiritual marketplace in contemporary Ghana', in H. Roy Chaudhuri \& R. Belk (eds.), Marketization, pp. 165-191, Springer, New York, NY

BBC News, n.d., Sani Abacha - the hunt for the billions stolen by Nigeria's ex-leader viewed n.d., from https://www.bbc.com/news/world-africa-54929254.

BBC News Pidgin, 2021, Viral video: For Covid pandemic, I buy my jet - Apostle Suleman, viewed n.d., from https://www.facebook.com/bbcnewspidgin/videos/viral-videofor-covid-pandemic-i-buy-my-jet-apostle-suleman/446764093441544/.

Beegle, K.G., Christiaensen, L., Dabalen, A.L. \& Gaddis, I., 2016, 'Poverty in a rising Africa', World Bank Group, viewed 01 June 2021, from http://documents. worldbank.org/curated/en/949241467996692059/Poverty-in-a-rising-Africa.

Boundless, 2020, 'Religion', Libretexts, viewed 03 June 2021, from https://socialsci. libretexts.org/Bookshelves/Sociology/Introduction_to_Sociology/Book\%3A Sociology_(Boundless)/14\%3A_Religion.

Burke, J., 2021, 'Jacob Zuma corruption trial in South Africa adjourned shortly after opening', The Guardian, viewed n.d, from https://www.theguardian.com/ world/2021/may/17/jacob-zuma-corruption-trial-in-south-africa-adjournedshortly-after-opening.

Carmody, M. 2009, 'Works of Karl Marx 1843: A contribution to the critique of Hegel's philosophy of right', Deutsch-Französische Jahrbücher, viewed 04 June 2021, from https://www.marxists.org/archive/marx/works/1843/critique-hpr/intro.htm.

CelebrationTV, 2018, 'Apostle Suleman please pay my rent, a widow cries out', YouTube, viewed n.d, from https://www.youtube.com/watch?v=JuN2fnm3Wag. 
Chin'ono, H., 2019, 'Robert Mugabe left millions of us in poverty and despair' The Guardian, viewed n.d. from https://www.theguardian.com/world/2019/ The Guardian, viewed n.d., from https://www.theguardian.com/world
sep/08/robert-mugabe-death-hero-tyrant-zimbabwe-hopewell-chinono.

Christiano, K.J., Swatos, W.H. \& Kivisto, P., 2008, Sociology of religion: contemporary developments, Rowman and Littlefield Publishers, Lanham, MD.

Cronin, J., 2018, 'Still an opium? Contemporary Marxists versus Karl Mark on the question of religion', London School of Economics, viewed 13 March 2021, from https://blogs.Ise.ac.uk/religionglobalsociety/2018/05/still-an-opium contemporary-marxists-versus-karl-marx-on-the-question-of-religion/.

Durkheim, E., 1897, Le suicide: Étude de sociologie, F. Alcan, New York, NY.

Fraser, G., 2009, 'Is religion the opium of the people?', The Guardian, viewed 15 February 2020, from https://www.theguardian.com/commentisfree/belief/2009/ jun/26/religion-philosophy.

eNCA, 2020, Malawi denies claims Bushiri took a ride with President Chakwera, viewed n.d, from https://www.enca.com/news/malawi-denies-claims-bushiritook-ride-president-chakwera.

Fraser, G., 2017, 'Why the soviet attempt to stamp out religion failed', The Guardian viewed 02 February 2021, from https://www.theguardian.com/commentisfree/ belief/2017/oct/26/why-the-soviet-attempt-to-stamp-out-religion-failed.

George, L., 2020, U.S., 'Jersey sign $\$ 300$ million Abacha loot repatriation deal with Nigeria', Reuters, viewed n.d., from https://www.reuters.com/article/us-usanigeria-idUSKBN1ZY1W0.

Gupta, S., Hamid D. \& Rosa, A., 2002, 'Does corruption affect income inequality and poverty?', Economics of Governance 3(1), 23-45.

Guyson, N., 2016, 'Of false prophets and profits: Meet the Pentecostal preacher taking on the prosperity gospel', African Arguments, viewed n.d, from https:// on the prosperity gospel', African Arguments, viewed n.d, from https://
africanarguments.org/2016/09/of-false-prophets-and-profits-meet-thepentecostal-preacher-taking-on-the-prosperity-gospel/.

Herbling, D., 2018, 'Kenyan deputy president seen as most corrupt leader in survey', Bloomberg, viewed n.d., from https://www.bloomberg.com/news/articles/201808-22/kenyan-deputy-president-seen-as-most-corrupt-leader-in-survey.

Hunt, J. \& Laszlo, S., 2012, 'Is bribery really regressive? Bribery's costs, benefits, and mechanisms', World Development 40(1), 355-372. https://doi.org/10.1016/j. worlddev.2011.06.001

Ivan, M., 2019, 'List: Top richest pastors in Uganda', Watchdog Uganda, viewed n.d, from https://www.watchdoguganda.com/entertainment/lifestyle/20200513/92367/listtop-richest-pastors-in-uganda.html.

Kaufmann, D., Kraay A. \& Mastruzzi, M., 2005, 'Governance matters IV: Governance indicators for 1996-2004', Policy Research Working Paper No. 3630. World Bank Washington, DC.

Keeley, B., 2015, Income inequality: The gap between rich and poor, pp. 66-67, OECD Publishing, Paris.

Kiewit, L. \& Rabkin, F., 2019, 'Former minister Bongani Bongo arrested on corruption charges', Mail \& Guardian, viewed n.d, from https://mg.co.za/article/2019-11-21 former-minister-bongani-bongo-arrested-on-corruption-charges/.

Mahdi, S., 2021, 'State of the Nation: Security and economic challenges', AlT Focus Nigeria, viewed 05 June 2021, from https://www.facebook.com/Oloyede733/ videos $/ 10222834967120461 /$ ?d $=w$.

McConnell, T., 2011, 'Uganda ministers charged with corruption', The World, viewed n.d., from https://theworld.org/stories/2011-10-06/uganda-ministers-chargedcorruption.

Merriam Webster, n.d., Opportunism, viewed n.d., from https://www.merriamwebster.com/dictionary/opportunism.

Mocan, N., 2008, 'What determines corruption? International evidence from microdata', Economic Inquiry 46, 493-510. https://doi.org/10.1111/j.1465-7295.2007.00107.x

Mogens, K. \& Bjørnskov, C., 2012, 'Exploiting the poor: bureaucratic corruption and poverty in Africa', Afrobarometer working papers, vol. 139, pp. 1-33, viewed 02 June 2021, from https://afrobarometer.org/publications/wp139-exploiting-poorbureaucratic-corruption-and-poverty-africa.
Muisyo, V., 2016, 'Malawi: Former president Bakili Muluzi corruption trial drags on', Africanews, viewed n.d., from https://www.africanews.com/2016/06/23/malawiformer-president-bakili-muluzi-corruption-trial-drags-on//.

National Institute of Statistics of Rwanda, 2016/17, The Fifth Integrated Household Living Conditions Survey Rwanda Poverty Profile Report EICV5, viewed n.d., from https://www.statistics.gov.rw/publication/eicv-5-rwanda-poverty-profilereport-201617.

Nations Online, n.d., Corruption perceptions index - Part I - The good, viewed n.d., from https://www.nationsonline.org/oneworld/corruption.htm.

Nkrumah, K., 1970, Consciencism: Philosophy and ideology for de-colonisation, Panaf Books, London.

Nyasa Times, 2017, 'Is Bushiri funding newly formed Malawian opposition party?', All Africa, viewed n.d., from https://allafrica.com/view/group/main/main/id/ 00054324.html.

Olaniyan, T., 2009, Arrest the music: Fela and his rebel art and politics, Bookcraft, Ibadan.

Önday, Ö., 2017, 'Understanding the economics of religion: Religeconomics', Ideastudies 4, 61-76. https://doi.org/10.26728/ideas.24

Pararan Mock News, 2021, 'Christ Embassy member sow seed with his family house, then pastor kick his parents out', YouTube, viewed 10 March 2021, from https:// www.youtube.com/watch?v=A7xQGxTTjlg.

Reuters, 2016, Former Nigerian ministers charged with laundering 4.9 billion naira, viewed n.d., from https://www.reuters.com/article/uk-nigeria-corruptionidUKKCNOZE2KB.

Sahara Reporters, 2021, I bought my third private jet during COVID-19 pandemic, prayed for disease to stay - Apostle Suleman, viewed n.d., from http://saharareporters. com/2021/02/17/i-bought-my-third-private-jet-during-covid-19-pandemic-prayeddisease-stay\%E2\%80\%94-apostle.

Shleifer, A., 1997, 'Government in transition', European Economic Review 41(1), 385-410. https://doi.org/10.1016/S0014-2921(97)00011-1

Statistics South Africa, 2019, National poverty lines, viewed n.d., from http://www. statssa.gov.za/publications/P03101/P031012019.pdf.

Thomas, Z., 2020, 'Full list of top 10 richest Pastors in Uganda', Eafeed, viewed 05 June 2021, from https://eafeed.com/top-10-richest-pastors-in-uganda2020-2021/.

Thompson, P., 2009, 'Not the opium, the endorphins', The Guardian, viewed 13 March 2021, from https://www.theguardian.com/commentisfree/belief/2009/jun/29/ marx-religion-atheism.

Thorlindsson, T. \& Bernburg, J.G., 2004, 'Durkheim's theory of social order and deviance: A multi-level test', European Sociological Review 20(4), 271-285.

Tsedu, M., 2020, 'Bushiri is now protected by UN protocols', SABC News, viewed 06 June 2021, from https://www.sabcnews.com/sabcnews/bushiri-is-nowprotected-by-un-protocols-mpho-tsedu/.

UNDP, 2017, Income inequality trends in sub-Saharan Africa: Divergence, determinants and consequences, viewed 02 June 2021, from https://www.africa.undp.org/ content/rba/en/home/library/reports/income-inequality-trends-in-sub-saharancontent/rba/en/home/library/rep
africa--divergence--dete.html.

United Nations Office on Drugs and Crime (UNODC), Nigeria, 2009, 'Business survey on crime and corruption', pp. 1-8, viewed 03 June 2021, from www.unodc.org/ on crime and corruption', pp. 1-8, viewed 03 June 2021, from www.unodc.org/
documents/data-and-analysis/statistics/corruption/Nigeria_report_exsum_2009. pdf.

U.S Department of States, 2015, John Kerry's remarks at the world economic forum, viewed 05 June 2021, from https://2009-2017.state.gov/secretary/remarks/ 2015/01/236254.htm.

Zachary, D., 2020, 'What is the future of poverty in Africa?', Daily Maverick, viewed 12 March 2021, from https://www.dailymaverick.co.za/article/2020-03-02-whatis-the-future-of-poverty-in-africa/. 